\title{
Microfinance and HIV/AIDS Prevention: Assessing its Promise and Limitations
}

\author{
Shari L. Dworkin · Kim Blankenship
}

Published online: 18 March 2009

(c) The Author(s) 2009. This article is published with open access at Springerlink.com

\begin{abstract}
Researchers increasingly argue that poverty and gender inequality exacerbate the spread of HIV/AIDS and that economic empowerment can therefore assist in the prevention and mitigation of the disease, particularly for women. This paper critically evaluates such claims. First, we examine the promises and limits of integrated HIV/ AIDS prevention and microfinance programs by examining the available evidence base. We then propose future research agendas and next steps that may help to clear current ambiguities about the potential for economic programs to contribute to HIV/AIDS risk reduction efforts.
\end{abstract}

Keywords Economic interventions · Microenterprise · HIV/AIDS prevention · Gender relations .

Gender equality · Women's HIV/AIDS risk

Over the past decade, HIV/AIDS prevention research has continued to shift from the individual, couple, and small group-level towards an analysis of the large-scale structural determinants of disease (Auerbach and Coates 2000; Blankenship et al. 2006; Gupta et al. 2008). Two of the most commonly identified structural determinants of HIV/ AIDS are poverty and gender inequality (Dworkin and Ehrhardt 2007; Gupta 2004; Parker et al. 2000). In turn, there is a recognized need for innovative structural

S. L. Dworkin $(\bowtie)$

Department of Social and Behavioral Sciences, University

of California at San Francisco, 3333 California Street,

LHTS \#455, San Francisco, CA 94143-0612, USA

e-mail: shari.dworkin@ucsf.edu; sharidworkin@earthlink.net

K. Blankenship

Department of Sociology and Duke Global Health Institute,

Duke University, Box 90519, Durham, NC 27708, USA approaches within the next generation of HIV/AIDS prevention interventions (Coates and Szekeres 2004; Friedman et al. 2006; Sumartojo et al. 2000).

Increasingly and globally, researchers are turning to microfinance programs with the hopes that they have found a viable site in which to achieve both poverty reduction and HIV/AIDS prevention (Anderson et al. 2002; Kim and Watts 2005; McDonagh 2001; Pronyk et al. 2005, 2006). Microfinance (MF) programs represent a range of programs that seek to alleviate poverty by providing access to credit, savings, or business skills. Such programs, which usually involve small amounts of money, are especially vital for the poor, particularly poor women, who are often excluded from educational opportunities, highly valued job skills, and traditional financial institutions and services (Jurik 2005; Pearson 2001).

MF programs are implemented in many varied ways (e.g., Morduch 1999; Copestake 2007; Sengupta and Aubuchon 2008), but some frequent features include group lending (small groups are formed voluntarily, loans are made to individuals within the groups, but all members are held responsible for loan repayment); progressive lending and dynamic incentives (loan size is increased with successful loan repayment); frequent and almost immediate loan repayment schedule; (often) compulsory savings (a portion of the loan placed in a group fund and strict rules for withdrawal applied); and either no collateral required or collateral substitutes permitted. Over time, and with success, MF institutions have added to these services by, for example, providing a variety of savings options, more flexible loan repayment, pension plans, insurance (debt relief with death of borrower, health insurance, natural disaster insurance), and business development services (Sengupta and Aubuchon 2008; Sievers and Vandenberg 2007). Although MF programs have often been run by institutions in the non-profit 
sector relying on donor financing, their success has prompted growing interest among commercial financial institutions leading some to question whether the former's emphasis on social performance and poverty reduction is jeopardized by the latter's emphasis on profitability and financial performance (e.g., Copestake 2007).

Several recent events highlight a trend of increasing research interest at the intersection of microfinance and HIV prevention. Domestically, in March of 2006, the CDC held a consultation on microfinance that centered on the Southeastern United States. Out of this consultation, a paper was recently published that called for the need to examine microfinance/microenterprise (ME) as an HIV risk reduction strategy (Stratford et al. 2008). In July of 2007, Yale University held a similar workshop that emphasized both domestic and international settings and considered whether microfinance influenced other health outcomes beyond HIV/ AIDS. The workshop was titled "Microfinance and beyond: structural interventions promoting economic opportunity as HIV risk reduction" (Hanck et al. 2007; Smoyer and Patterson 2007). Additionally, several recent International AIDS Conferences showcased new research projects that examined how microfinance assists HIV infected households, reduces stigma against those with HIV/AIDS, and empowers women to protect themselves from HIV. Finally, microfinance received even more public notoriety in 2006 when Muhammad Yunnus won the Nobel Peace Prize for his vision, leadership, and work with Grameen Bank in Bangladesh.

What helps to explain the growing popularity of integrating MF and HIV research agendas? First, MF is viewed as a promising strategy for mitigating the economic impact of HIV/AIDS for those who are HIV affected (Barnes, 2003, 2005; Parker, 2000). Second, a growing literature examines the sustainability of MF organizations in settings where households and communities (and hence, microfinance clients) are greatly affected by HIV/AIDS; here, the microfinance industry is particularly concerned about clients' ability to pay back loans in regions where there is a mature epidemic (Gommans 2006; Green and Bundred 2006; Mayoux 2001). Finally, there is increased interest in whether MF can work as an HIV/AIDS prevention strategy (Kim and Watts 2005; Kim et al. 2008; Pronyk et al. 2008a, b; Stratford et al. 2008). In this work, we focus on the last interest-HIV/AIDS prevention-due to the recognized need for innovative structural approaches to prevention.

\section{Why Consider Microfinance as an HIV/AIDS Prevention Strategy?}

At first glance, an emphasis on economic empowerment as a prevention strategy seems urgent. Research findings indicate that economically disempowered or dependent women and girls are more likely to be constrained into sexually risky situations: less able to negotiate safer sex with partners, less likely to be able to leave an abusive or violent relationship (which also increases HIV risks), and much more likely to exchange sex for material goods or assets (Exner et al. 2003; Hallman 2004). Additionally, some research has found that many women who do sex work are first inducted and partly trapped into it for economic reasons (Manopaiboon et al. 2003; Tan Minh et al. 2004). Research now also shows that poverty affects girls and women more negatively than boys and men with regard to unsafe sex; and that economic independence for women is an important predictor of being able to negotiate safer sex (Grieg and Koopman 2003; Hallman 2004). MF then, to the extent that it provides women alternative sources of income and promotes their economic empowerment, may promote HIV prevention. In addition, HIV prevention education and skills training may be another "service" attached to MF programs. Thus, by combining HIV/AIDS prevention and MF, important synergies may be produced that extend beyond the economic realm to provide more enduring "structural protection" from HIV/ AIDS risks than HIV/AIDS prevention can do alone.

\section{Does Microfinance Actually Reduce Women's HIV Risks?}

Very few integrated economic/HIV prevention programs have been tested domestically or internationally to answer this question. One domestic pilot study known as the JEWEL program (Jewelery Education for Women Empowering Their Lives) examined the efficacy of an integrated HIV/economic program for drug using sex workers in Baltimore, Maryland (Sherman et al. 2006). The program offered six, 2-hour HIV prevention sessions and assisted women with the making, marketing and selling of jewelry. Using a pre-post test design, researchers found significant reductions both in receiving drugs or sex for money and in the median number of sex trade partners per month. And, at 3 month follow-up, income earned from the sales of jewelry was associated with a reduction in the number of sex partners.

Of the programs that integrate HIV/MF, only one randomized controlled trial has been conducted. The IMAGE Program (Intervention for Microfinance and Gender Equity) tested the effect of an integrated MF and HIV/ AIDS prevention intervention on violence and HIV outcomes. Based in Limpopo, South Africa, it involved collaboration between the Small Enterprise Foundation (SEF), the Rural Aids and Development Action Research (RADAR), and the London School of Tropical Hygiene. IMAGE innovatively merged a curriculum of gender 
equity, anti-violence work, and HIV/AIDS education with an existing MF program (Pronyk et al. 2005). The authors reported a 55\% reduction in domestic violence at 1 year for program participants compared to controls (Pronyk et al. 2006). More recent results from the same project underscore that this integrated initiative changed numerous indicators of "women's empowerment" in positive directions (Kim et al. 2008). Finally, the most recently published results highlighted that young women who took part in the intervention showed significantly higher levels of HIV-related communication, were more likely to have accessed voluntary counseling and testing, and were less likely to have had unprotected sex at last intercourse with a non-spousal partner (Pronyk et al. 2008b). However, neither HIV incidence nor the rate of unprotected sex among youth living in the households of intervention participants were significantly affected, although both were defined as primary outcome variables for the study (Pronyk et al. 2006). This suggests that the intervention is more effective for direct participants in the program than for those who received the intervention messages through diffusion.

Several international studies also suggest a reduction in violence resulting from participation in economic programs, although none of these involve either a randomized design or an emphasis on HIV. For example, Schuler et al. (1996) found that participants in a credit program in Bangladesh were less likely to be beaten than non-credit participants or than those who lived in villages where credit is not an option. Similarly, Hashemi et al. (1996) found that participation in a credit program was associated with a statistically significant reduction in the incidence of violence against women. Qualitative data from several studies revealed similar themes, with women in credit programs reporting that their husbands hit them less often after participation, especially when loans came into the household (Hashemi et al. 1996; Hays-Mitchell 1999; Kabeer 1998).

The grey literature contains results from several other integrated economic/HIV prevention interventions. These programs are worth noting since most MF programs are developed for adult women (Sharif 2001) and it is young women who are disproportionately at risk of HIV/AIDS in several regions of the world. One program, titled SHAZ! (Shaping the Health of Adolescents in Zimbabwe) was developed by researchers at UCSF, carried out in Harere, and combined business training and mentoring, microcredit loans, life-skills training, and HIV prevention for 1619 year old out-of-school orphaned and poor girls.

The SHAZ! research team found that HIV knowledge and relationship power were positively impacted by participation in the program. At the same time, the young women had difficulty paying back loans, and some young women were subjected to sexual abuse and exploitation as a result of carrying out their daily business practices (IPPF and UNFPA 2006). Additionally, most businesses were not very successful unless young women had previous business experiences or capital, family support, or alternative sources of additional financial support (Dunbar et al. 2009). Some of the findings are likely due to the very difficult macroeconomic environment in the region that was facing unprecedented levels of inflation and substantial economic instability. At the same time, the lessons learned from this project are quite important, and a second iteration of the project will emphasize more graduated savings, a more holistic approach to young women's needs, and will try to balance the need for best practices in microfinance with the fact that none of the participants would have received loans to begin with if best practices were followed (Dunbar et al. 2009).

A second integrated economic/HIV program with youth was known as TRY-Tap and Reposition Youth and was carried out in an impoverished shanty area of Nairobi, Kenya with $15-19$ year olds. TRY participants were significantly more likely than members of a control group to insist on condom use and refuse sex, although their condom use was not higher (IPPF and 2006). Notably, savings were found to be much more important to young women than loans to start businesses. These findings indicate that HIV researchers should not seek a "one-size-fits-all" approach to economic programs and should tailor product offerings to the target needs of the population.

\section{Does Microfinance "Empower" Women and What are the Implications for HIV Researchers?}

In general, MF programs appear to have increased access to credit among those who would not typically have such access, produced high rates of repayment, and increased per capita household consumption (especially as a result of women's borrowing) and school enrollment (Chemin 2008; Sengupta and Aubuchon 2008; Khandker 2005). Specific features of these programs may make them more or less successful in different circumstances. For example, group loan lending may be less successful than individual lending in urban areas, or in low density rural areas; and dynamic incentives may be less effective where there is greater competition among MF institutions (Navajas et al. 2000). Further, research suggests that it is the marginally poor, rather than the poorest of the poor who benefit most from these programs (Chemin 2008; Morduch 1999, Sengupta and Aubochon 2008; Navajas et al. 2000). Some therefore argue that those who are most at risk of HIV are overlooked as viable MF program participants due to way in which microfinance business practices tend to designate those most in need as lacking "creditworthiness" (Jurik 2005). 
Much work remains to be done at this important intersection and HIV/AIDS research in this area has only begun. Turning to other disciplines to examine the empowering impacts that MF has is therefore instructive. Indeed, Schuler and Hashemi (1994), Hashemi et al. (1996), and Amin et al. (1998) found that participation in MF significantly improved women's household decision-making, household authority, and autonomy. A meta-analysis of existing MF programs reveals that these programs are best at changing women's level of individual agency and intrahousehold bargaining power (Mahmud 2003).

Several studies to date have also found that MF participation leads to increased reproductive health decisionmaking power (contraceptive use for fertility decisions, including both traditional and non-traditional methods of contraception). Schuler and Hashemi (1994) found this in a study of MF participants in rural Bangladesh. Similarly, qualitative work by Hays-Mitchell (1999) in Peru also shows that women report having more control over fertility decisions (timing/spacing of births of children) after participation in a credit program. These authors all suggest that some women find that a source of income gives them a platform of increased power from which to negotiate with male partners. Taken together, the above findings underscore that HIV/AIDS researchers would be wise to use validated measures of sexual relationship power in future work and to assess whether economic programs also shape women's sexual relationship power.

Notably, women's lending groups may also offer group solidarity and identity outside of family ties. This is potentially important for risk reduction efforts, since some researchers see this form of social capital as an "associational mechanism" that fosters critical thinking, reflection and the catalyst for social change that can impact health. Indeed, Rose (1992), Larance (1998), Pronyk et al. (2008a) and Sanyal (2008) all find evidence that social capital and associational mechanisms were important factors in shaping the ability of women to fight issues at the intersection of health and gender inequality (e.g., violence against women, male partners who are heavy alcohol users and then demand unsafe sex). While these group processes are powerful and appear to show great potential as catalysts for social change, it is not clear if this is the mechanism through which HIV/ AIDS risks would be effectively reduced-or if it is the economic element - or both (Pronyk et al. 2008a).

\section{What are the Limitations of Microfinance Programs to Reduce Women's HIV Risks?}

Despite its benefits, MF has several key limitations. First, even though programs have shown some promise concerning improvements in household power related to finances, health, or fertility decisions, these results may not necessarily transfer to safer sex negotiations. To be sure, the processes involved in making household purchases or negotiating for a smaller family size are not the same ones that influence sexual risk taking in a dyad or household. It may be the case that increases in bargaining power derived from MF participation do translate into improved safer sex negotiations, but HIV researchers need to further understand how MF may work to bring about these changes.

Second, the loans associated with MF programs are often very small, and programs would be more accurately viewed as increasing the ability of households to survive rather than as "economic empowerment" that may in fact reduce HIV risks. Of note, it is also true that women of different races, classes, ages, and industries experience widely varying economic benefits of income generation programs due to women's different social positioning (Jurik 2005; Pearson 2001). This fact points to the potentially limited success of microfinance to fundamentally alter larger structures of inequality (race, class, age, gender, sexuality, caste) in a given region (Mayoux 1998; Skarlatos 2004; Rahman 1999; Selinger 2008).

Third, while some studies show a reduction in violence after participating in an economic program, several programs report that violence against women increases. One study from Bangladesh revealed that domestic violence worsened from women's participation in a microcredit program (Rahman 1999). The authors explain that MF organizations sometimes inflict an intense pressure on women to repay loans. Repayment pressures can considerably increase household debt liability and can intensify marital conflict, a finding also reported by Hashemi et al. (1996). At the same time, while some researchers find that improved mobility or social capital empower women, implying that programs may be protective of risk, just as many others find that improved mobility increases women's sexual risks through increased access to sexual partners, abuse, or opportunities (Hirsch et al. 2007; Measham 2004), an outcome also seen in both the SHAZ! and TRY programs. These mixed findings indicate that no program is a magic bullet and that all programs must be developed with a nuanced understanding of local contexts and the state of gender relations on the ground.

Fourth, it may be the case that it is not absolute levels of income that are most important for bargaining power or improvements in vulnerability to risk, but relative income levels coupled with control over assets (Goetz and Gupta 1995). This point has been made in recent arguments concerning the ways in which property rights and ownership and control of property may be protective of HIV/AIDS risks (ICRW 2006). Such research points to the need for more work that carefully takes the relative income, assets, control over assets, and the occupational standing of the couple into account when examining health outcomes. 
Fifth, there is a great deal of regional variation in the field of microfinance itself concerning its stage of development, the types of programs deployed (individual versus group lending, and many of the other previous distinctions made), the degree of regulation that is found (e.g., ranging from an early stage of development and highly unregulated versus a more mature industry that is more regulated), and the flexibility that programs offer to meet women's specific needs (e.g., registering assets in women's names, or both members of the household, modifying loan size, timing, or payback requirements). Indeed, at times, HIV researchers may not have seen resoundingly positive outcomes concerning the impact of integrated HIV and economic programs because it has been difficult to adhere to best practices in the microfinance industry (Dunbar et al. 2009). However, some researchers argue that best practices need to be reconsidered altogether in order to ensure that women actually benefit from MF programs (Mayoux 2002). Garnering - and publishing-lessons learned about best practices will aid future researchers to balance accepted practices with what women need to benefit from microfinance programs. At the same time, when integrations occur the other way around-e.g., when microfinance groups seek to integrate HIV prevention activities into operations - it is vital that HIV researchers assist intensively with what constitutes the best genderspecific HIV/AIDS prevention that is available.

\section{What to Conclude? What Next?}

There are several conclusions to be drawn. First, as a standalone intervention, microfinance programs show mixed results and may - or may not-offer a significant degree of economic empowerment or independence from male partners. If HIV researchers want to hang their hat on the "economic empowerment" angle of microfinance as a route to reduce risks, it may be better to view programs as providing minor improvements in the ability of households to economically survive. Additionally, we truly do not know much about whether it is economics per se or other aspects of programs (e.g., social capital, group level collective action) that may drive HIV risk reduction or other health outcomes. Finally, more research is clearly needed on which economic components-combinations of components-and institutional missions in MF organizationsmight yield reduced HIV risks.

While stand-alone economic interventions do not focus centrally on HIV prevention and we therefore should not expect large changes in HIV/AIDS risks, we see great promise in considering integrated HIV prevention and economic interventions. Indeed, the skill sets taught in microfinance initiatives may produce unique synergies with the skill sets that are necessary to help women to negotiate safer sex (assertiveness, recognition of gender norms, challenging gender norms, and practicing new enactments of agency and independence). Studies are sorely needed to foster more understanding of the mechanisms through which sexual and economic empowerment operate (e.g., self-efficacy, autonomy, control, household-decision making, social capital, community empowerment, skills building, sexual relationship power) to achieve health outcomes.

Second, in those programs that focus on MF and safer sex negotiations, research has clearly not demonstrated the desired results in terms of condom use or HIV risk reductions. While the IMAGE project did test the effects that an integrated economic/HIV program had on safer sex, HIV incidence and safer sex outcomes were not positively affected at 1 year follow-up, and hence additional challenges and questions remain. While a dramatic reduction of violence was found in this intervention in the experimental arm, and research tells us that violence and HIV are associated (Jewkes et al. 2003; Maman et al. 2002), it may take more time to show a decrease in HIV incidence than intervention follow-up times allow. Questions also remain as to what the best "doses" are for the gender-specific HIV/AIDS prevention and economic empowerment components of any integrated intervention, and these issues should be further explored.

Third, this review speaks to the need for rigorous trials to test if the risk reduction effects of an integrated microfinance and HIV/AIDS prevention program are significantly greater than our best gender-specific HIV/AIDS prevention alone. The need for rigorous trials is especially important given that, with the exception of the IMAGE study, none of the studies analyzing the effect of microfinance on women's empowerment used a randomized controlled design. Most studies therefore failed to account for selection bias (were the individual participants in MF programs simply more motivated than other women?) and village level effects (were villages where MF programs are located substantially different from those that do not have MF programs?) when carrying out the analysis. If these factors were controlled for, it may be the case that non-MF participating women who contribute financially to the household also enjoy "empowerment" or that women's household decisionmaking also increases if they live in an area where credit programs already exist (Pitt et al. 1999).

Fourth, it is vital to underscore the importance of antiviolence work for integrated MF/HIV prevention interventions. Given the very promising results concerning reductions in violence in IMAGE project, and the known association between violence and HIV/AIDS risks (Dunkle et al. 2006; Jewkes et al. 2003), there is a clear need to continue to integrate anti-domestic violence work into $\mathrm{MF}$ / HIV prevention interventions. Even stand-alone MF programs should consider contingency and safety planning 
around backlash tendencies, particularly given the mixed results found on the relationship between MF and domestic violence.

Lastly, future research should certainly seek to understand the impact of MF on men and men's reactions to perceived or actual improvements in women's status. Furthering research in this area would prove to be very useful in attempting to understand how men view specific combinations of gender equity, HIV/AIDS prevention, and MF. An emphasis on gender relations and not just women is urgent given that there is already a level of recognition that MF programs explicitly challenge gender norms (by supporting women's business practices, knowledge, and mobility, and improving women's ability to contribute to household income). It may in fact be the case, then, that additional gender equity or HIV/AIDS prevention components add to these challenges. These considerations point to the urgent need for future research to consider developing programs that involve both women and men in communities at the outset of the program planning phase. Programs should also ensure that sessions assist with critical reflections on gender norms, masculinity, and gender equity, particularly where gender relations are changing the most rapidly or are highly constraining (Kim and Watts 2005; Mantell et al. 2006).

\section{Conclusions}

Millions of poor women around the world have already been reached through economic initiatives, and millions more who are at risk of HIV could feasibly be reached for prevention purposes. It is likely that such integrations will be increasingly sought out by both the development and HIV/AIDS arenas. This trend should not be surprising given that the United Nations Millennium Development Goals have firmed up the tripartite commitment to improve women's empowerment, decrease poverty, and fight HIV/ AIDS. It is our hope that these critical considerations and suggested future research plans will help to move the field forward when thinking about the benefits and limitations of programs that seek to simultaneously intervene on women's economic and sexual empowerment.

Acknowledgments This research was supported by center grant P30-MH43520 from NIMH to the HIV Center for Clinical and Behavioral Studies (Anke A. Ehrhardt, Ph.D., Principal Investigator). The authors gratefully acknowledge comments provided by the anonymous reviewers at AIDS \& Behavior. We are also grateful for generous insights and comments provided by Susie Hoffman, Anke Ehrhardt, Jenny Higgins, and Abbey Hatcher.

Open Access This article is distributed under the terms of the Creative Commons Attribution Noncommercial License which permits any noncommercial use, distribution, and reproduction in any medium, provided the original author(s) and source are credited.

\section{References}

Amin, R., Becker, S., \& Bayes, A. (1998). NGO promoted microcredit programs and women's empowerment. Journal of Developing Areas, 32, 221-236.

Anderson, C. L., Gugerty, M. K., \& Levine, R.O.Weaver, M. (2002). Microfinance and HIV/AIDS: Five key questions on program impact. CHER (Center for Health Education and Research). Seattle, WA. Available at: http://www.synergyaids.com/ documents/AdvancesSeriesMicrofinance3Oct03.pdf. Accessed 10 March 2007.

Auerbach, J., \& Coates, T. J. (2000). HIV prevention research: accomplishments and challenges for the third decade of AIDS. American Journal of Public Health, 90, 1-7. doi:10.2105/ AJPH.90.7.1029.

Barnes, C. (2003). Microfinance and households coping with HIV/ AIDS: An exploratory study. New York: The population council. Available at: http://www.popcouncil.org/pdfs/horizons/ microfinzimbfnl.pdf. Accessed 25 March 2005.

Barnes, C. (2005). Microcredit and households coping with HIV/ AIDS: A case study from Zimbabwe. Journal of Microfinance, 7, 55-77.

Blankenship, K., Friedman, S., Dworkin, S., et al. (2006). Structural interventions: challenges and opportunities for interdisciplinary research. Journal of Urban Health, 83, 59-72. doi:10.1007/ s11524-005-9007-4.

Chemin, M. (2008). The benefits and costs of microfinance: Evidence from Bangladesh. The Journal of Development Studies, 44, 463484. doi:10.1080/00220380701846735.

Coates, T. J., \& Szekeres, G. (2004). A plan for the next generation of HIV Prevention research: Seven key policy investigative challenges. The American Psychologist, 59, 747-757. doi:10.1037/ 0003-066X.59.8.747.

Copestake, J. (2007). Mainstreaming microfinance: Social performance management or mission drift? World Development, 35, 1721-1738. doi:10.1016/j.worlddev.2007.06.004.

Dunbar, M. S., Maternowska, C., Kang, M. J., Laver, S. M., Mudekunye, I., Padian, N.S. (2009) Findings from SHAZ!: A feasibility study of a microcredit and life-skills HIV prevention intervention to reduce risk among adolescent female orphans in Zimbabwe. Journal of Prevention \& Intervention in the Community, in press.

Dunkle, K. L., Jewkes, R. K., Nduna, M., Levin, J., Jama, N., Khuzwayo, N., et al. (2006). Perpetration of partner violence and HIV risk behaviour among young men in the rural Eastern Cape, South Africa. AIDS (London, England), 20, 2107-2114. doi:10.1097/01.aids.0000247582.00826.52.

Dworkin, S., \& Ehrhardt, A. A. (2007). Going beyond ABC to include GEM (gender relations, economic contexts, and migration movements): Critical reflections on progress in the HIV/AIDS epidemic. American Journal of Public Health, 97, 13-16. doi:10.2105/AJPH.2005.074591.

Exner, T., Hoffman, S., Dworkin, S., \& Ehrhardt, A. A. (2003). Beyond the male condom: The evolution of gender-specific HIV interventions for women. Annual Review of Sex Research, 14, 114-136.

Friedman, S. R., Kippax, S. C., Phaswana-Mafuya, N., Rossi, D., \& Newman, C. E. (2006). Emerging future issues in HIV/AIDS Social Research. AIDS (London, England), 20, 959-965.

Goetz, A. M., \& Gupta, R. S. (1995). Who takes the credit: Gender, power, and control over loan use in rural credit programs in Bangladesh. World Development, 24, 45-63. doi:10.1016/ 0305-750X(95)00124-U.

Gommans, C. (2006). Partners and action: Financial institutions and health, HIV \& AIDS risk management. Paper presented at risk 
management of HIV/AIDS conference, Cape Town, South Africa, April 242006.

Green, C., \& Bundred, F. (2006). Mitigating the impact of AIDS on microfinance institutions: Are we making progress? USAID. Available at http://www.microlinks.org/. Accessed October 12 2006.

Grieg, F. E., \& Koopman, C. (2003). Multilevel analysis of women's empowerment and HIV prevention: Quantitative survey results from a preliminary study in Botswana. AIDS and Behavior, 7, 195-208. doi:10.1023/A:1023954526639.

Gupta, G. R. (2004). Globalization, women, and the HIV/AIDS epidemic. Peace Review, 16, 79-83. doi:10.1080/1040265 042000210201.

Gupta, G. R., Parkurst, J. O., Ogden, J. A., Aggleton, P., \& Mahal, A. (2008). Structural approaches to HIV Prevention. Lancet, 764 775. doi:10.1016/S0140-6736(08)60887-9.

Hallman, K. (2004). Socioeconomic disadvantage and unsafe sexual behaviors among young women and men in South Africa. Policy research division working paper no. 190. New York: Population Council.

Hanck, S., West, B., \& Tsui, S. (2007). Can microfinance programs reduce HIV risk in developing countries? Policy update. New Haven: Center for Interdisciplinary Research on AIDS, Yale University.

Hashemi, S., Schuler, S., \& Riley, A. (1996). Rural credit programs and women's empowerment in Bangladesh. World Development, 23, 635-653. doi:10.1016/0305-750X(95)00159-A.

Hays-Mitchell, M. (1999). From survivor to entrepreneur: gendered dimensions of microenterprise development in Peru. Environment and Planning, 31, 251-271. doi:10.1068/a310251.

Hirsch, J., Meneses, S., Thompson, B., Negroni, M., Pelcastre, B., \& del Rio, C. (2007). The inevitability of infidelity: Sexual reputation, social geographies, and marital risk in rural Mexico. American Journal of Public Health, 97, 986-996. doi:10.2105/ AJPH.2006.088492.

ICRW.(2006). Reducing women's and girl's vulnerability to HIV/ AIDS by strengthening their property rights. Available at: http://www.icrw.org/docs/2006_proprghtsinfobull.pdf. Accessed March 102008

IPPF and UNFPA. (2006). Change, choice, and power: Young women, livelihoods and HIV prevention-literature review and case study analysis. Available at: http://www.unfpa.org/ upload/lib_pub_file/674_filename_change.pdf. Accessed January 152008 .

Jewkes, R. K., Levin, J. B., \& Penn-Kekana, L. A. (2003). Gender inequalities, intimate partner violence and HIV preventive practices: findings of a South African cross-sectional study. Social Science and Medicine, 56, 125-134.

Jurik, N. (2005). Bootstrap Dreams: U.S. Microeconomic Development in an Era of Welfare Reform. Ithaca: Cornell University Press.

Kabeer, N. (1998). 'Can buy me love'? Re-evaluating the empowerment potential of loans for women in rural Bangladesh. Institute of development studies, Sussex, UK. Available at: http://www.ids.ac.uk/ids/bookshop/dp/Dp363.pd. Accessed March 222006.

Khandker, S. R. (2005). Microfinance and poverty: evidence using panel data from Bangladesh. World Bank Economic Review, 19, 263-286.

Kim, J., \& Watts, C. H. (2005). Gaining a foothold: Tackling poverty, gender inequality, and HIV in Africa. BMJ, 331, 769-772.

Kim, J., Watts, C. H., Hargreaves, J. R., Ndhlovu, L. X., Phetla, G., Morison, L. A., et al. (2008). Understanding the impact of a microfinance based intervention on women's empowerment and the reduction of intimate partner violence in South Africa. American Journal of Public Health, 97, 1794-1802.
Larance, L. Y. (1998). Building social capital from the center: a village-level investigation of Bangladesh's Grameen Bank. Grameen Trust Working Paper. Available at: http:// www.gdrc.org/icm/grameen-lisa.pdf. Accessed March 152005.

Mahmud, S. (2003). Actually how empowering is microcredit. Development and Change, 34, 577-605.

Maman, S., Mbwambo, J. K., Hogan, N. M., et al. (2002). HIVpositive women report more lifetime partner violence: Findings from a voluntary counseling and testing clinic in Dar es Salaam, Tanzania. American Journal of Public Health, 92, 1331-1337.

Manopaiboon, C., Bunnell, R. E., Kilmarx, P. H., et al. (2003). Leaving sex work: Barriers, facilitating factors, and consequences for female sex workers in northern Thailand. AIDS Care, 15, 39-52.

Mantell, J., Dworkin, S., Exner, T., Hoffman, S., \& Susser, I. (2006). The Promises and limitations of female-initiated methods of HIV/STI protection. Social Science and Medicine, 63, 19982009.

Mayoux, L. (1998). Women's empowerment and micro-finance programmes: Strategies for increasing impact. Development in Practice, 8, 235-241.

Mayoux, L. (2001). Tackling the down side: Social capital, women's empowerment and micro-finance in Cameroon. Development and Change, 32, 435-464.

Mayoux, L. (2002). Microfinance and women's empowerment: Rethinking best practice. Development Bulletin, 57, 76-80.

McDonagh, A. (2001). Microfinance strategies for HIV/AIDS mitigation and prevention in Sub-Saharan Africa. Available at: http://www. ilo.org/public/english/employment/finance/download/wpap25.pdf. Accessed August 102006.

Measham, D. M. (2004). Gender-based power and susceptibility to sexually transmitted infections among women in Karnataka state, India (dissertation). Berkeley: University of California.

Morduch, J. (1999). The microfinance promise. Journal of Economic Literature, 37, 1569-1614.

Navajas, S., Schreiner, M., et al. (2000). Microcredit and the poorest of the poor: Theory and evidence from Bolivia. World Development, 28, 333-346.

Parker, J. (2000). Discussion paper: Microfinance and HIV/AIDS. USAID microenterprise best practices. Available at: http://www. iaen.org/library/parker.pdf. Accessed March 252005.

Parker, R., Easton, D., \& Klein, C. (2000). Structural barriers and facilitators in HIV prevention: A review of international research. AIDS, 14, S22.

Pearson, R. (2001). Microcredit as a path from welfare-to-work: The experience with the full circle project, UK. In B. Lemire, R. Pearson, \& G. Campbell (Eds.), Women and credit: Researching the past, refiguring the future (pp. 167-181). New York: Berg.

Pitt, M. M., Khandker, S. R., Mckernan, S. M., \& Abdul Latif, A. (1999). Credit programs for the poor and reproductive behavior in love income countries: Are the reported causal relationships the result of heterogeneity bias? Demography, 36, 1-21.

Pronyk, P. M., Kim, J. C., Hargreaves, J. R., Makhubele, M. B., Morison, L. A., Watts, C. H., et al. (2005). Microfinance and HIV prevention: Perspectives and emerging lessons from rural South Africa. Small Enterprise Development, 16, 26-38.

Pronyk, P. M., Hargreaves, J. R., Kim, K., Morison, L. A., et al. (2006). Effect of a structural intervention for the prevention of intimate partner violence and HIV in rural South Africa: Results of a cluster randomized trial. Lancet, 368, 1973-1983.

Pronyk, P. M., Harpham, T., Morison, L. A., Hargreaves, J. R., Kim, J. C., Phetla, G., et al. (2008a). Is social capital associated with HIV risk in rural South Africa. Social Science and Medicine, 66, 1999-2010.

Pronyk, P., Kim, J. C., Abramsky, T., Phetla, G., Hargreaves, J. R., Morison, L. A., et al. (2008b). A combined microfinance and 
training intervention can reduce HIV risk behavior in young female participants. AIDS, 22, 1659-1665.

Rahman, A. (1999). Women and microcredit and rural Bangladesh: An anthropological study of Grameen bank lending. Boulder: Westview Press.

Rose, K. (1992). Where women are leaders: The SEWA movement in India. London: Zed Books.

Sanyal, P. (2008). From credit to collective action: The role of microfinance in women's social capital and normative influence. (dissertation) Cambridge: Harvard University.

Schuler, S. R., \& Hashemi, S. M. (1994). Credit programs, women's empowerment, and contraceptive use in rural Bangladesh. Studies in Family Planning, 25, 65-76.

Schuler, S. R., Hashemi, S. M., Riley, A. P., \& Akhter, S. (1996). Credit programs, patriarchy, and men's violence against women in rural Bangladesh. Social Science and Medicine, 43, 17291742.

Selinger, E. (2008). Does microcredit "empower"? Reflections on the Grameen bank debate. Human Studies, 31, 27-41.

Sengupta, R., \& Aubuchon, C. P. (2008). The microfinance revolution: An overview. Federal Reserve Bank of St. Louis Review, 90, 9-30.

Sharif, N. R. (2001). Poor female youth and human capital development in Bangladesh: What role for microcredit programmes? In B. Lemire, R. Pearson, \& G. Campbell (Eds.), Women and Credit: Researching the Past, Refiguring the Future (Pp 223-244). New York: Berg.
Sherman, S. G., German, Y., Cheng, M., Marks, M., \& BaileyKloche, M. (2006). The evaluation of the JEWEL project: An innovative economic enhancement and HIV prevention intervention study targeting drug using women involved in prostitution. AIDS Care, 18, 1-11.

Sievers, M., \& Vandenberg, P. (2007). Synergies through linkages: who benefits from linking micro-finance and business development services? World Development, 35, 1341-1358.

Skarlatos, K. (2004). Microfinance and women's economic empowerment: Bridging the gap, redesigning the future. Wisconsin coordinating council on Nicaragua Available at: http:// www.wccnica.org/node/155. Accessed March 222006.

Smoyer, A. B., \& Patterson, H. R. (2007). Can microenterprise programs reduce HIV risk in the United States? Policy Update. New Haven: Center for Interdisciplinary Research on AIDS, Yale University.

Stratford, D., Mizuno, Y., Williams, K., Courtenay-Quirk, C., \& O'Leary, A. (2008). Addressing poverty as risk for disease: Recommendations from CDC's consultation on microenterprise as HIV prevention. Public Health Reports, 123, 9-20.

Sumartojo, E., Doll, L., Holtgrave, D., Gayle, H., \& Merson, M. (2000). Enriching the mix: Incorporating structural factors into HIV prevention. AIDS, 14(S1), S3-S10.

Tan Minh, T., Thi Nhan, D., West, G. R., Durabnt, T. M., Jenkins, R. A., Thi Huong, P., et al. (2004). Sex workers in Vietnam: How many, how risky? AIDS Education and Prevention, 16, 389-404. 